Iranian Journal of Breast

Diseases. 2022; 14(1):64-77
Original Article

\section{Fabrication and Characterization of Liposomal Nanoparticles Containing Hydroalcoholic Extract of Artemisia Absinthiumand Its Toxicity against MCF-7 Breast Cancer Cell Line}

\author{
Taebpour $\mathrm{M}^{1}$, Majdizadeh $\mathrm{M}^{2}$, Haghiralsadat $\mathrm{BF}^{3,4^{*}}$ \\ ${ }^{1}$ Department of Advanced Medical Sciences and Technologies, School of \\ Paramedicine, ShahidSadoughi University of Medical Sciences, Yazd, Iran \\ ${ }^{2}$ Nano-Biotech Foresight Company Biotechnology Campus, Science \& Technology \\ Park of Yazd, Yazd, Iran \\ ${ }^{3}$ Medical Nanotechnology \& Tissue Engineering Research Center, Yazd \\ Reproductive Sciences Institute, ShahidSadoughi University of Medical Sciences, \\ Yazd, Iran \\ ${ }^{4}$ Department of Advanced Medical Sciences and Technologies, School of \\ Paramedicine, ShahidSadoughi University of Medical Sciences, Yazd, Iran
}

\begin{abstract}
Introduction: The use of chemotherapy drugs has side effects, and the use of herbal compounds in the treatment of cancer faces challenges. Nanoparticles, especially liposomes, with appropriate properties in drug delivery, such as slow drug release and low toxicity at the target cell site, can solve some of these problems. Therefore, the aim of the present study was to develop a liposomal system containing Artemisia absinthium extract and to investigate its toxicity against the MCF-7 cell line.
\end{abstract}

Methods: Three liposomal systems containing extracts with different molar percentages of soybean phosphatidylcholine (80\% and 60\%) along with cholesterol were prepared using the thin-film hydration method. The most suitable formulation was selected according to the loading percentage and release rate. Extract release from the selected formulation, particle size, and zeta potential were investigated. Finally, the toxicity of the extractloaded system, the free extract, and the unloaded system against the MCF-7 cell line was measured.

Results: Extract loading, particle size, dispersion index, and zeta potential for the selected formulation are $49.2 \% \pm 0.4 \%, 121.9 \mathrm{~nm}, 0.129$, and -10.6 $\mathrm{mV}$. The system showed a slow release at temperatures similar to healthy and cancer cells. Also, the liposome-encapsulated extract was more toxic against MCF-7 cells compared with the free extract, and extract-free liposomes had little toxicity against MCF-7 cells.

Conclusion: The liposomal system containing Artemisia absinthium extract has a higher toxicity than the free extract against breast cancer cells, which can be due to the physicochemical properties of the system, including targeted release.

Keywords: Nanoparticles, Liposome, Artemisia absinthium, MCF-7 
مقاله بِروهشى ساخت و مشخصه يابى نانوذرات ليبوزومال حاوى عصاره هيدروالكلى

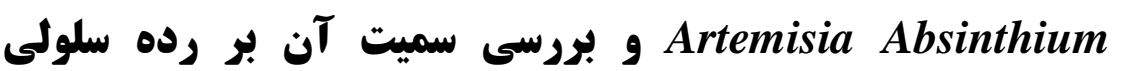
MCF-7

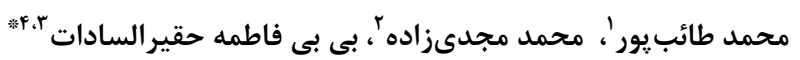
' كروه علوم و فنون نوين يزشكى، دانشكده يِيرايزشكى، دانشگاه علوم يزشكى و خدمات درمانى شهيد صدوقى يزد، يزد، ايران

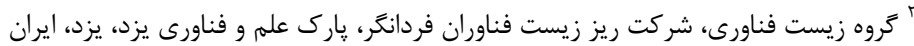

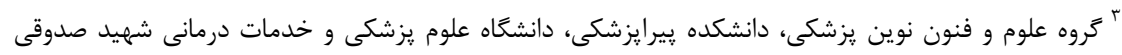
يزد، يزد، ايران

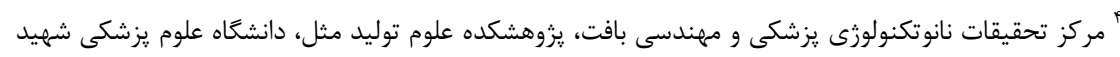
صدوقى يزد، يزد، ايران
فصلنامه بيمارى هاى يستان ايران

$1 \varepsilon \cdots ! \mid \varepsilon(1): 7 \varepsilon-w$

\section{our?}

مقدمه: استفاده از داروهاى شيمىدرمانى داراى عوارض جانبى و استفاده از تركيبات كياهى در درمان

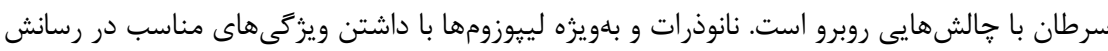

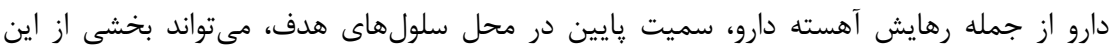

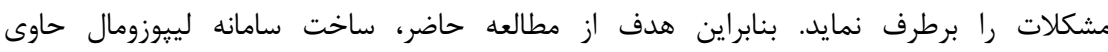

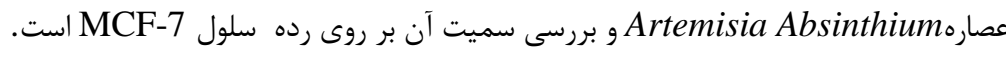

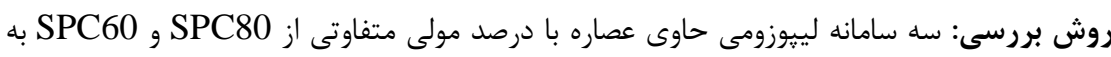

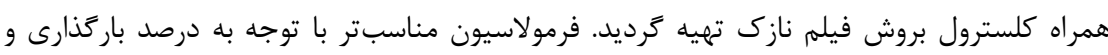

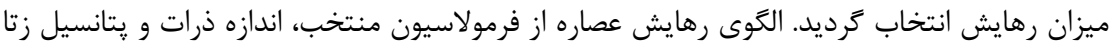

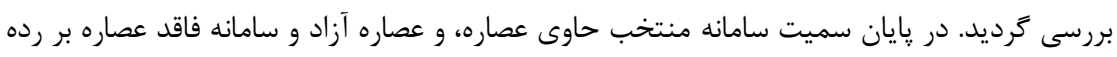
سلولى MCF-7 سنجيده شدريل در سائ سميت سند يافتهها: ميزان باركذارى عصاره، اندازه ذرات، شاخص يراكندگى، و يتانسيل زتا براى فرمولاسيون

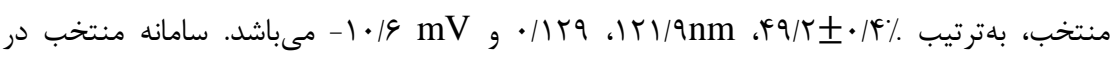

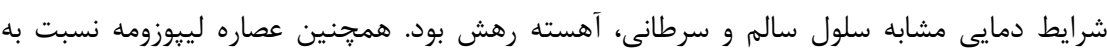

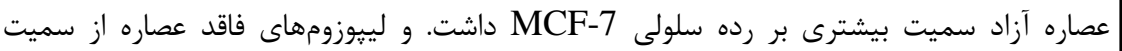
نإجيزى بر رده سلولى MCF-7 برخوردار است. نتيجهَيرى: سامانه منتخب لييوزومى حاوى عصاره Artemisia Absinthium از سميت بالاترى

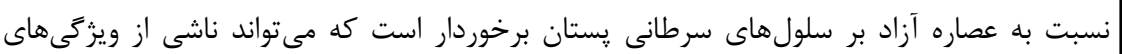

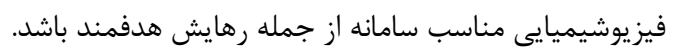
| وازههاى كليدى: نانو ذرات، ليبوزوم، افسنطين، MCF-7

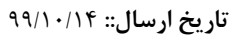

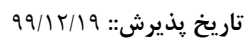

$$
\text { "نويسنده مسئول: }
$$
Fhaghirosadat@gmail.com 
از خانواده Asteraceae، كياهى علفى است كه به دليل

برخوردارى از تركيبات فنولى و فلاوونوئيدى كه جزء

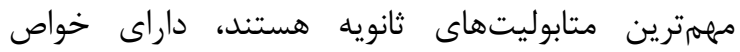

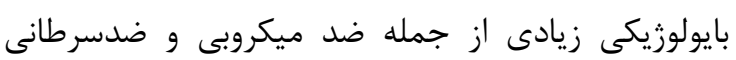

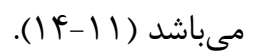

با وجود تمامى فوايد كياهان دارويى در درمان و يِيشگيرى

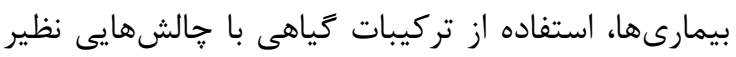

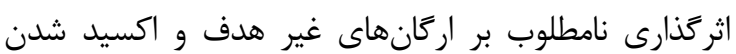

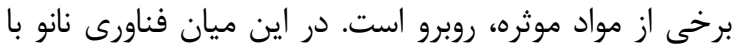

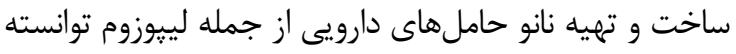

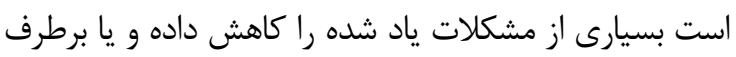
نمايد (ها). لييوزومهاى نانو حاملهاى ليبيدى هستند كه

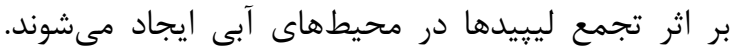

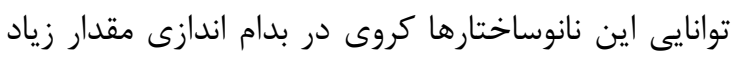

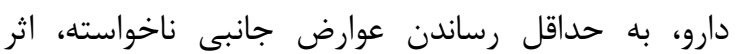
بخشى بالا و سميت يايين توانسته علاقه محققين را به

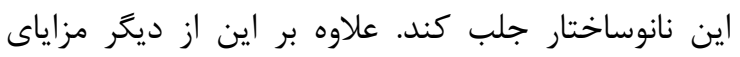
نانولييوزومها مىتوان به سهولت توليد حجمهاى صنعتى، كيفيت عالى ساخت، تنوع در اندازه ذره، تركيب شيميايى

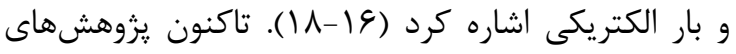
متعددى بر روى سامانهاى ليييدى به منظورئ

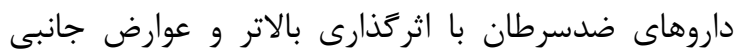
كمتر انجام شده است. به عنوان نمونه داروى اونى وايد،

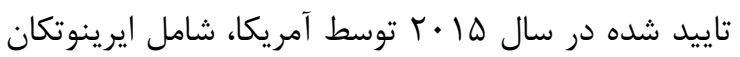

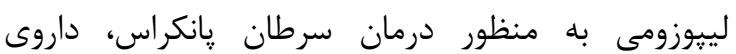

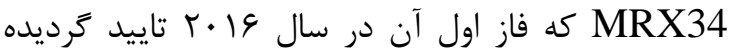
است بلمنظور درمان سرطانهاى ييشرفته، داروى ماركيبو

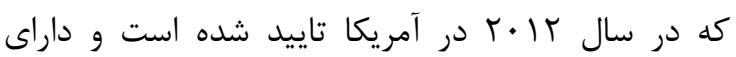
سولفات وينكريستين لييوزومى است، به منظور درمان

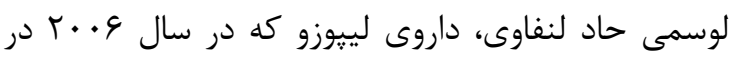

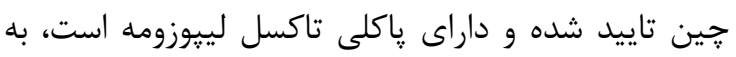
منظور درمان سرطان تخمدان و پِتان، داروى Myocet

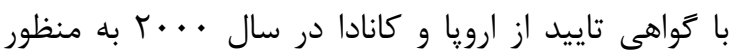

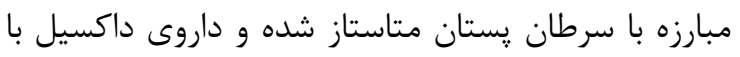

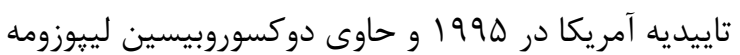
به منظور درمان سرطان تخمدان، مثالهايى از داروهايى

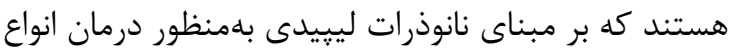
سرطان توليد گرديدهاند (19) مبناي ناندرات ليبيل
سرطان باعنوان يكى از عوامل مههم مرگ و مير، مانعى

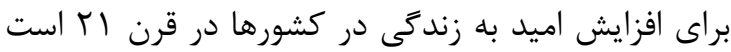

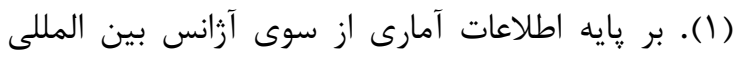

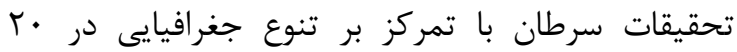

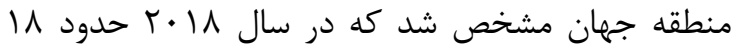

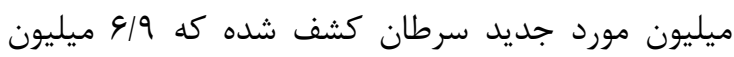
مورد آن منجر به مرك شده است (ז). مطالعات نشان داده كه تومور در انسان يك فرايند جند مرحلداى است كه

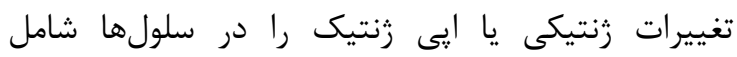

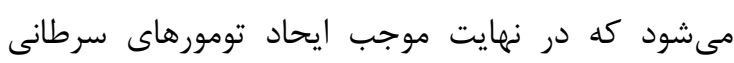
مىشود (ب). عليرغم بِيشرفتهاى قابل توجه در زمينه

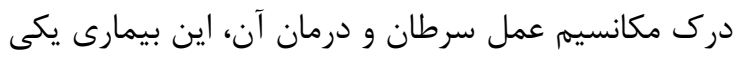

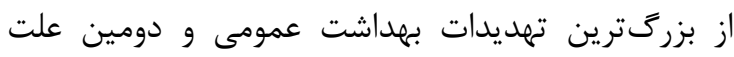

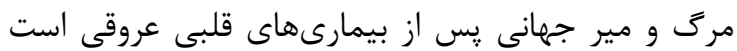

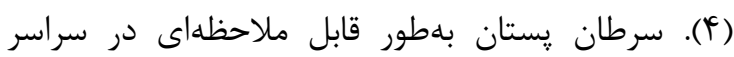

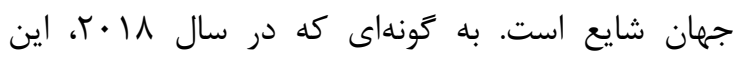

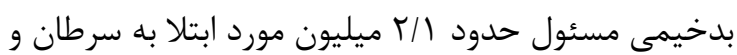
קنجمين علت مرگ و مير ناشى از سرطان در سراسر

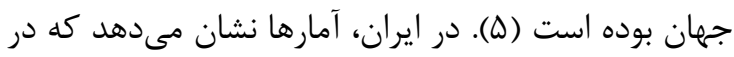

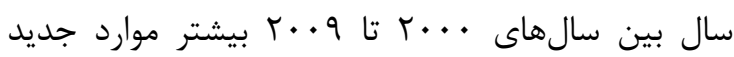
ابتلا به سرطان در جامعه زنان ايرانى مربوط سرطان

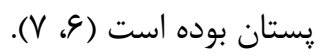

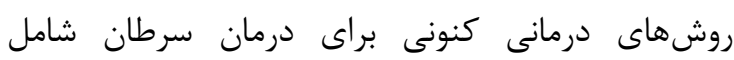

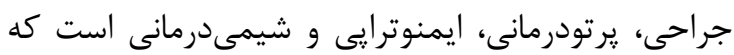
هركدام با عوارض جانبى مختلفى همراه است (^). زيرا هيج يك از درمانهاى ياد شده هدفمند نيستند و بلهعنوان

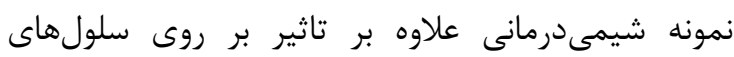

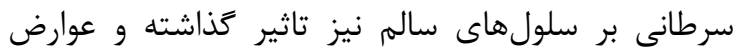

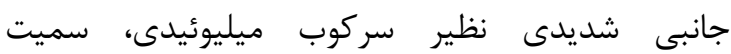

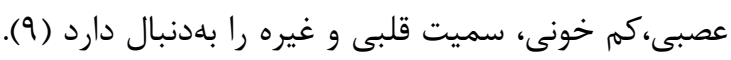
بنابراين كياهان با داشتن تركيبات سيتوتوكسيك نظير

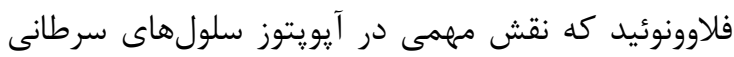

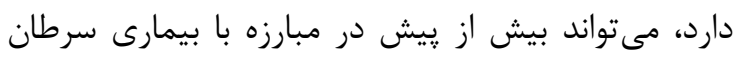

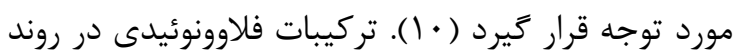
سرطانزايى با مسيرهاى انتقال سيخنال هاى متعدد تداخل

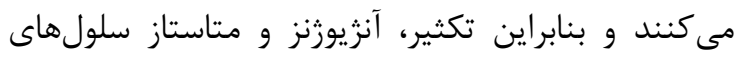

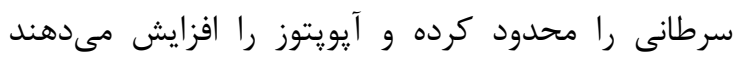
(•) (1). افسنطين با نام علمى Artemisia Absinthium 
شيشهاى منتقل شد و به مدت جهار روز در دماى دهاى

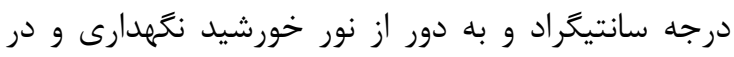

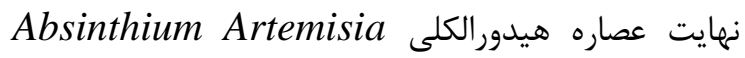

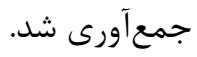

Artemisia رسم نمودار استاندارد عصاره Absinthium در حلال ايزويروييل و فسفات سالين براى رسم نمودار استاندارد ابتدا عصاره مورد نظر در بافر

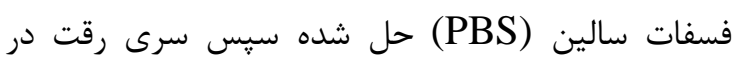

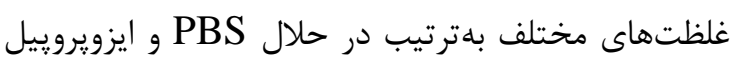
ساخته شده و جذب هر كدام به صورت جداكانه با استفاده

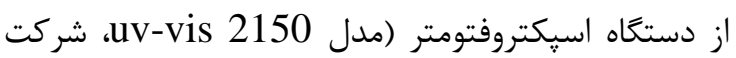
UNICO موجهاى جذبى بهدست آمده بلترتيب نمودار استاندارد درد

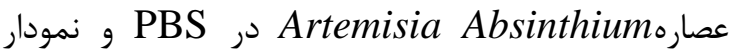

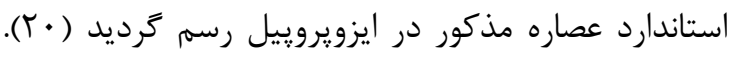
تمامى آزمايشات اين مرحله با ب مرتبه تكرار انجام كرديده

تهيه لييوزوم حاوى عصاره براى ساخت فرمولاسيونهاى لييوزومهاى حاوى عصاره Artemisia Absinthium از روش هيدراتاسيون فيلم نازك استفاده شده است كه خلاصه آن به شرح زير است: ابتدا كلسترول و نوع مشخصى از فسفاتيديل كولين سويا

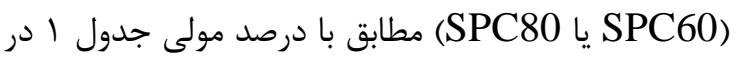
حلال كلروفرم و در دماى C. C بر روى روتارى (شركت

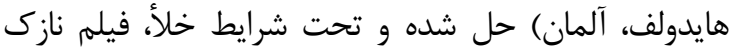

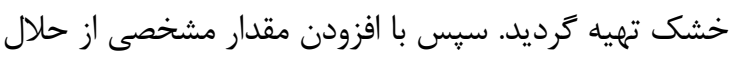

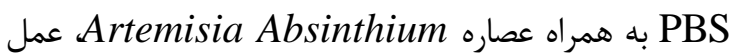
هيدراتاسيون در دماى Fa C

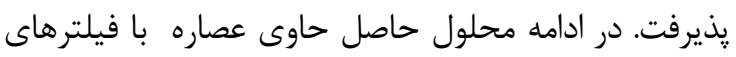

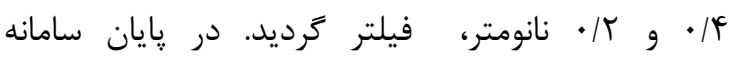
لييوزومى حاوى عصاره، بهمنظور كاهش سايز با استفاده از

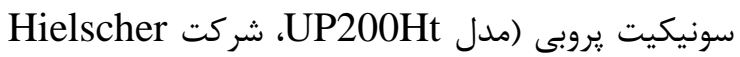

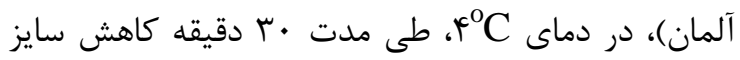

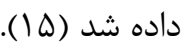

هدف از يزوهش حاضر، ساخت سامانه ليِيوزومى حاوى عصاره Artemisia Absinthium با استفاده

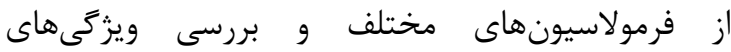

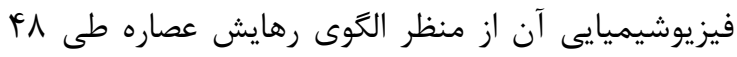

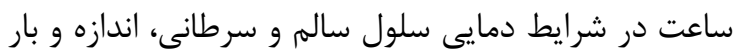

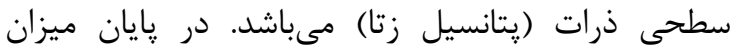

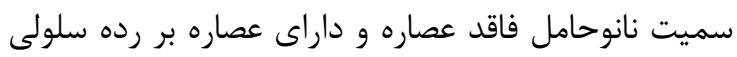
MCF-7 مىرود كه نتايج اين يزوهش بتواند، مسيرى در جهت بان

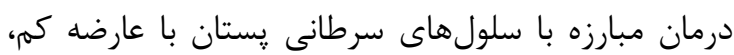

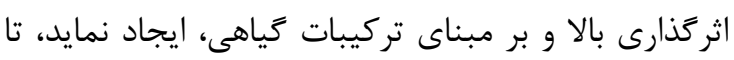
بيماران مبتلا به اين بيمارى در طول درمان از كيفيت إنان بالاترى در زندگى خود برخوردار باشند. بيدا دينا

\section{مواد و روشها}

يزوهش حاضر نوعى مطالعه آزمايشكاهى از نوع كاربردى

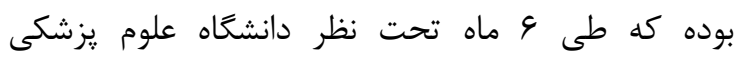

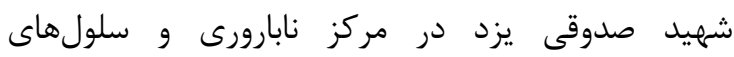

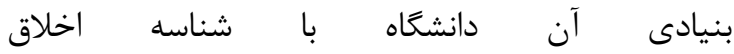
IR.SSU.RSI.REC.1398.038 به آن انجام رسيده است. در اين مطالعه ضمن ساخت و مطالعهى ويزّكىهاى

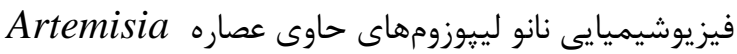
Absinthium به بررسى سميت عصاره لييوزومه و آزادي عاد MCF-7 بrtemisia Absinthium سرطان يستان با استفاده از كنترل منفى يرداخته شده رداء

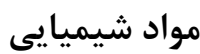
فسفاتيديل كولين سويا •1 و و •4 متعلقيائ به شركت lipoid-Gmbh sigma-Aldrih

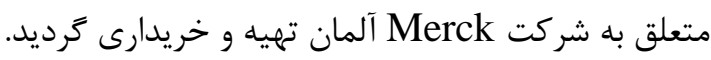

عصارهكيرى از كياه Artemisia Absinthium

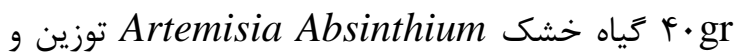

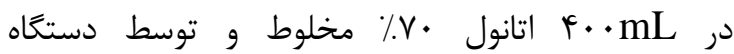
سوكسوله عصاره اتانولى آن يس از از سه ساعت، استخراج

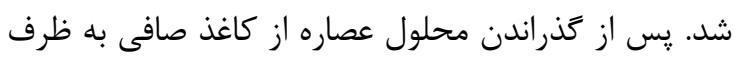


جدول ا: نوع و درصد فسفوليييد و درصدكلسترول براى ساخت سامانههاى لييوزومى حاوى عصاره

\begin{tabular}{lcccc}
\hline Formula Code & Lipid/Drug & SPC60 (\%) & SPC80 (\%) & Cholestrol (\%) \\
\hline F1 & 1. & $\cdot$ & $\wedge \cdot$ & $r \cdot$ \\
F2 & $1 \cdot$ & $\wedge \cdot$ & $\cdot$ & $r \cdot$ \\
F3 & $1 \cdot$ & r. & $\cdot$ & $r \cdot$ \\
\hline
\end{tabular}

تعيين درصد باركذارى عصاره در سامانه لييوزومىى

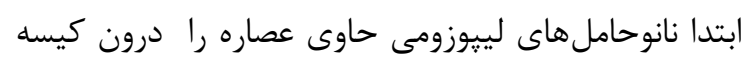

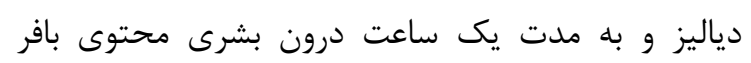

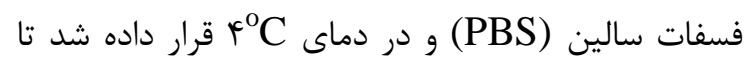
عصاره باركذارى نشده حذف كردد. سيس لييوزومهاى

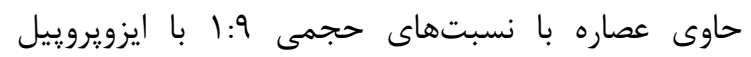

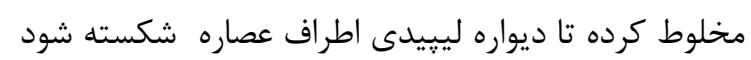

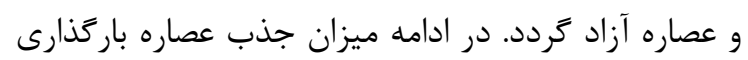

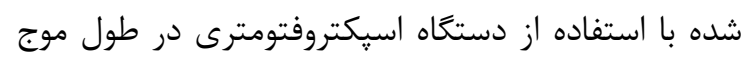

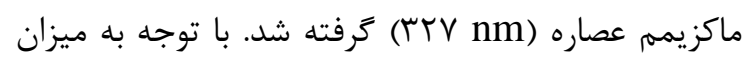
جذب بهدست آمده و تطبيق آن با نمودار استاندارد عصاره

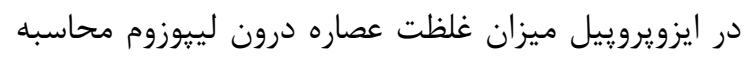

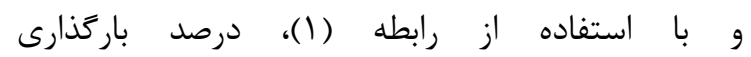
عصاره Artemisia Absinthium در لييوزومها محاسبه

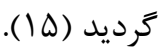

ارزيابى ميزان و الكوى رهايش عصاره از سامانههاى ليبيوزومى اليقى براى ارزيابى ميزان رهايش عصاره باركذارى شده در در

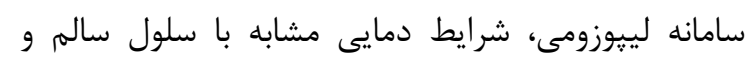

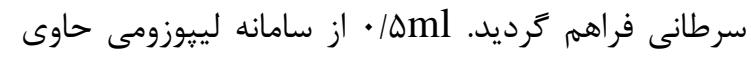

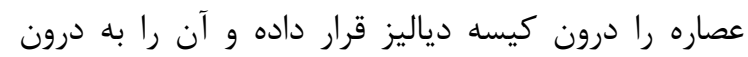

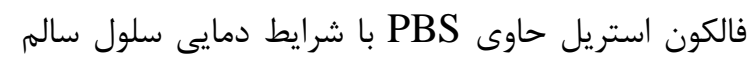
و شرايط دمايى سلول سرطانى (YV (Y C C

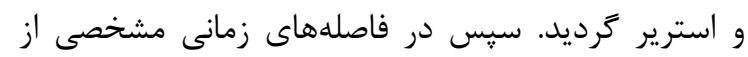

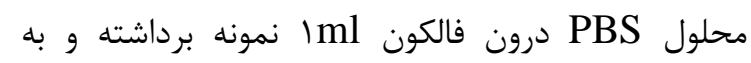

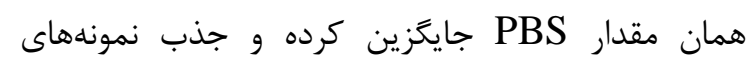

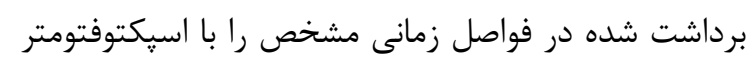

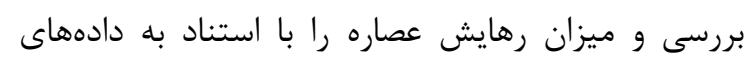

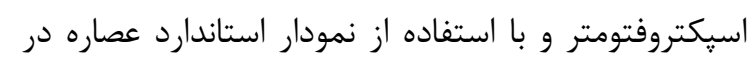
PBS رابطه (1):

$$
\text { EntrapmentEfficiency }(\% E E)=\frac{\text { EncapsulatedDrugConcentration }}{\text { PrimaryusedDrugConcentration }} \times 100
$$

\section{تعيين سميت سلولى و درصد زندهمانى}

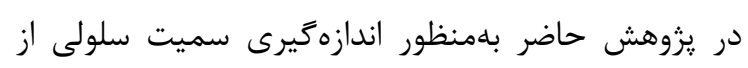

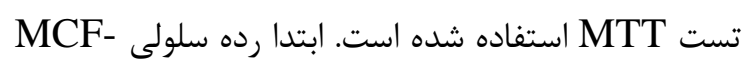

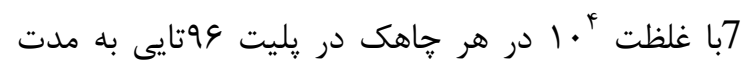

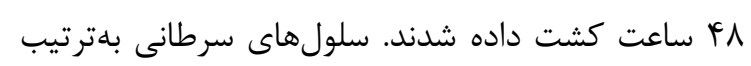
با

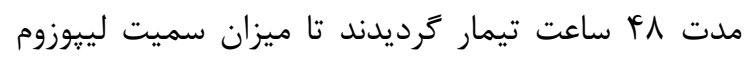

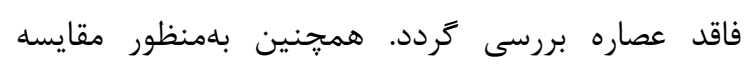

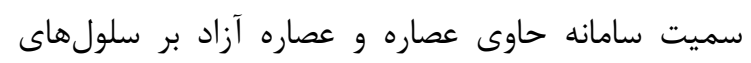

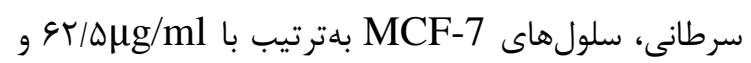

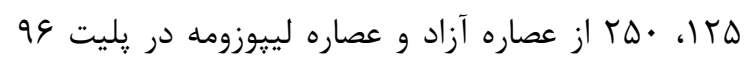

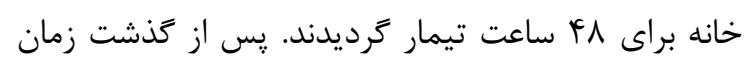

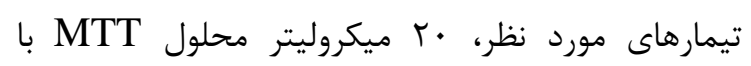

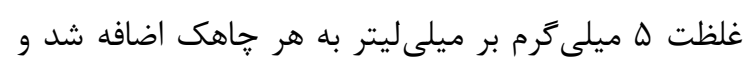

\section{تعيين اندازه و يتانسيل زتا ذرات سامانه لييوزومى}

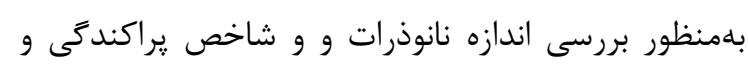

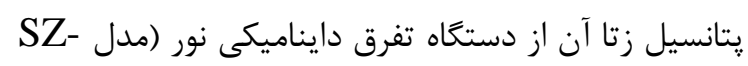
100z Dynamic Light Scattering \& Zeta (Horiba شركت در دماى :potential analyzer

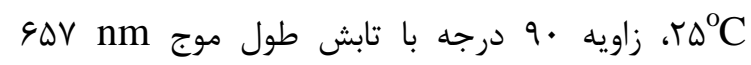
استفاده گرديد.

\section{رده سلولى و محيط كشت}

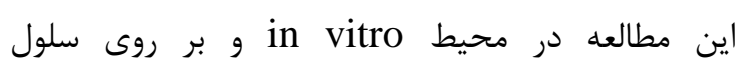

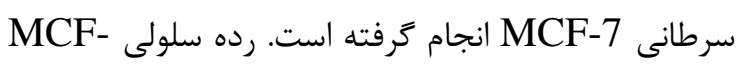

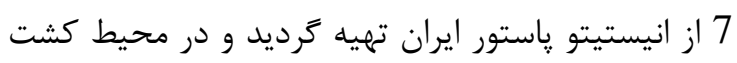
DMEM

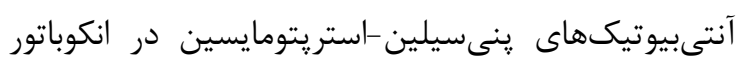

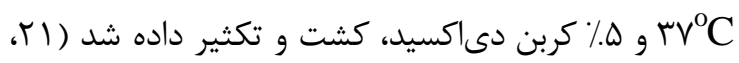


شركت Biotek آمريكا) ثبت و در نهايت با توجه به رابطه

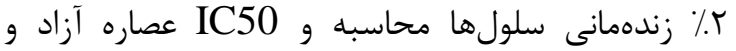
سامانه لييوزومى حاوى عصاره بر روى رلى سلولهاى سرطانى MCF-7 كزارش شد.
به مدت F أعاعت انكوبه شدند. بعد از آن مايع رويى خارج

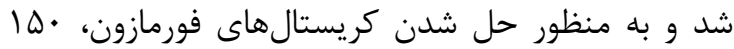
ميكروليتر DMSO اضافه كرديد. جذب در طول موج

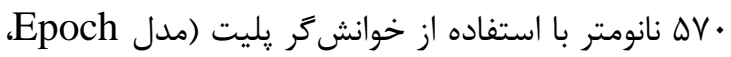

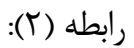

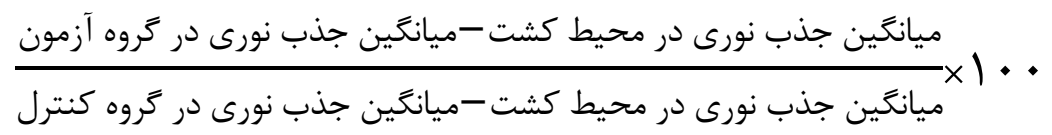

نتايج حاصل از زتا سايزر نشان مىدهد كه اندازه و يتانسيل زتا و شاخص زراكندگى ذرات سازنده سامانه

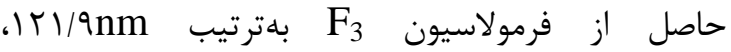

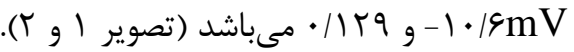

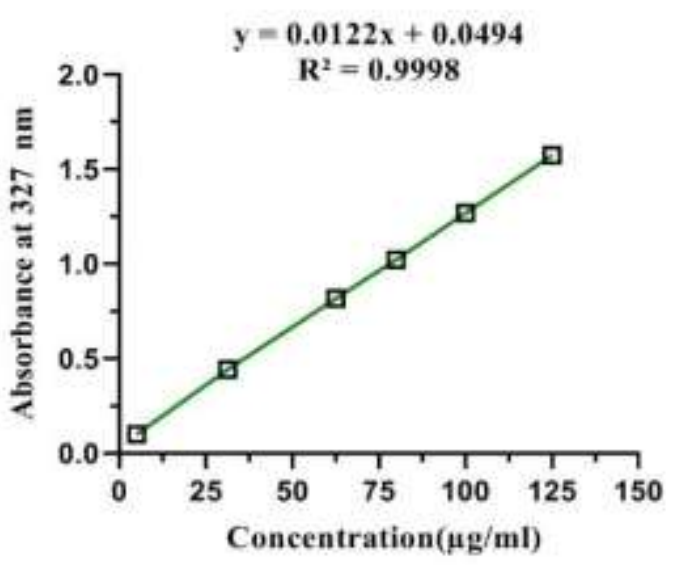

Artemisia نمودار ا: نمودار استاندارد عصاره Absinthium در حلال ايزويرويانول

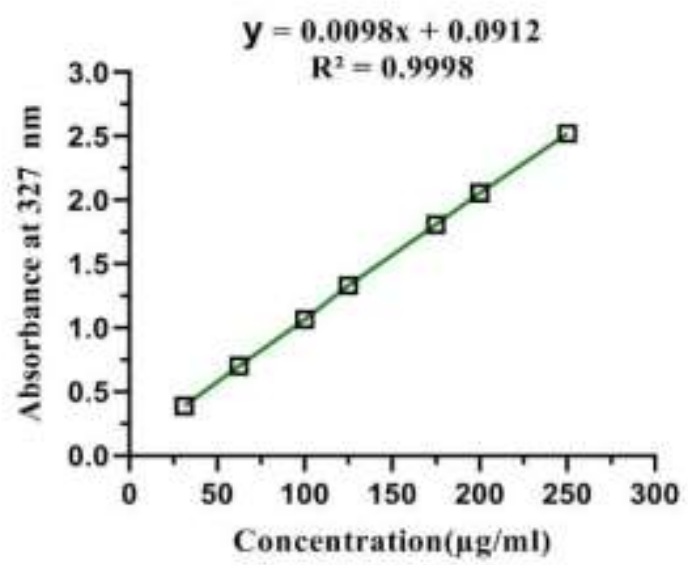

Artemisia نمودار r: نمودار استاندارد عصاره PBS Absinthium
آناليزهاى آمارى

در يزوهش حاضر به منظور تفسير دادههاى عددى حاصل

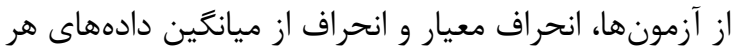

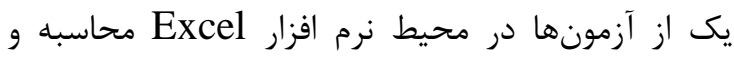

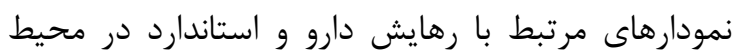

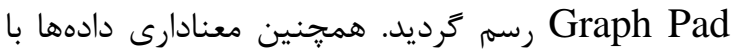

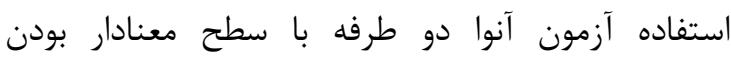

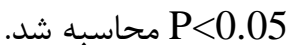

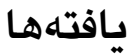

نتايج حاصل از بررسى باركذارى و رهايش عصاره از

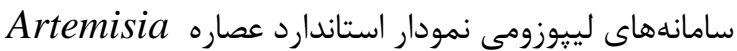
Absinthium در حلال ايزويرويانول و PBS در طول

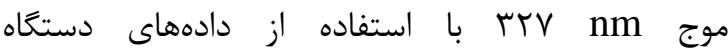

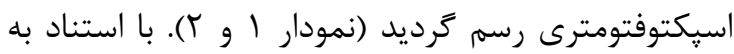
نمودار استاندارد عصاره Artemisia Absinthium در برد

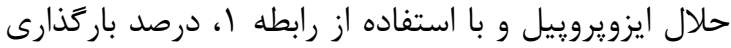
عصاره در لييوزومهاى حاصل از فرمولاسيونهاى Fل

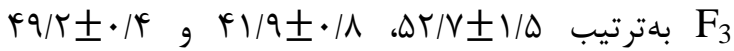
درصد محاسبه شد. همجنين با استفاده از نمودار استاندارد

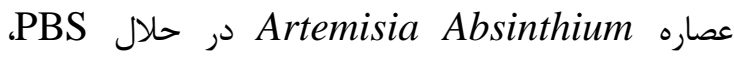
ميزان رهايش عصاره، از هر يك از فرمولاسيونها مطابق جدول r كزارش گرديد.

انتخاب فرمولاسيون مناسب

از ميان سامانههاى ساخته شده با فرمولاسيونهاى Fi Fر بر اساس ميزان باركذارى عصاره و الكَى رهايش

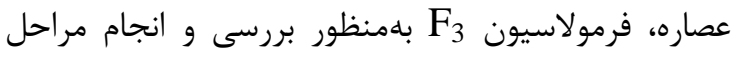
بعدى آزمايش انتخاب كرديد.

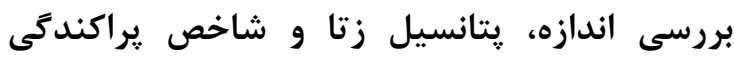

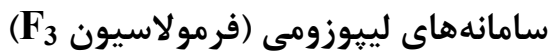




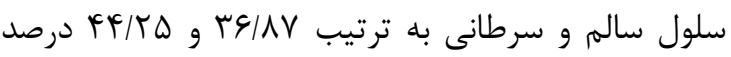

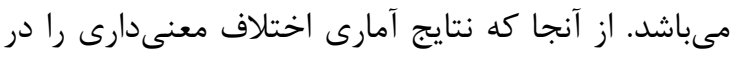
زمانهاى مختلف نمونهبردارى بين دماى

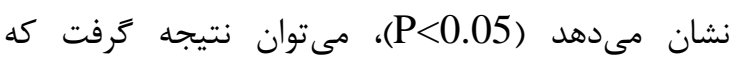

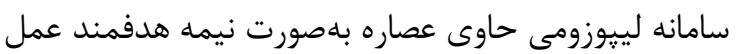

$$
\text { مى كند (تصوير ץ). }
$$

بررسى سيميت نانو سامانه لييوزومال حاوى عصاره

\section{Artemisia Absinthium}

بررسى نتايج حاصل از تست سميت سلولى 4 باعته ساعه عصاره Artemisia Absinthium بر رده سلول سرطانى نتائ ساصل نشان داد كه سميت عصاره لييوزومه شده

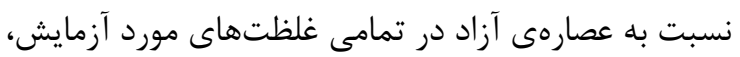

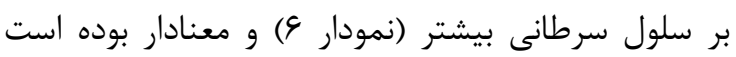

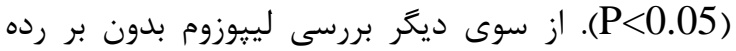
سلول سرطانى MCF-7 نشان مى دهد كه اين نانو سامانه

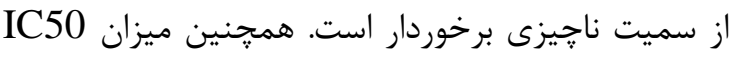

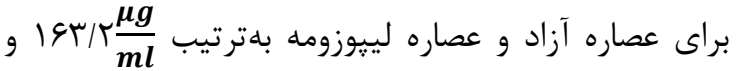

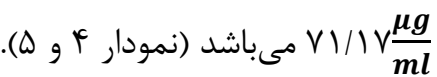

جدول | : ميزان باركذارى و رهايش عصاره Artemisia Absinthium در فرمولاسيون مختلف و دمايش

\begin{tabular}{|c|c|c|c|}
\hline فرمول & رهايش ر راعت) & $\begin{array}{l}\text { رهايش) } \\
\text { (هIF) }\end{array}$ & 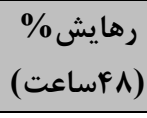 \\
\hline$F_{1}$ & $r \cdot / / r$ & $r \Delta / / f$ & $r \cdot / \uparrow \wedge$ \\
\hline$F_{2}$ & G/NG & $r V / 19$ & TF/YA \\
\hline$F_{3}$ & rq/9) & rq/ & rGIAV \\
\hline
\end{tabular}

بررسى الكوى رهايش عصاره Artemisia ف Absinthium فرمولاسيون Fo نمودار رهايش عصاره Artemisia Absinthium از نانوذرات حاصل از فرمولاسيون F3 با استفاده از نمودار

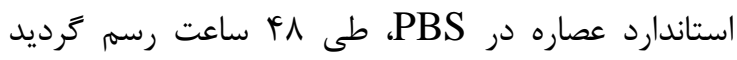

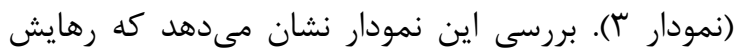
عصاره از ذرات لييوزومى در شرايط دمايى مشابه سلول

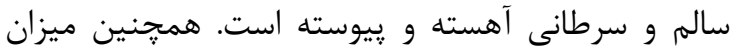

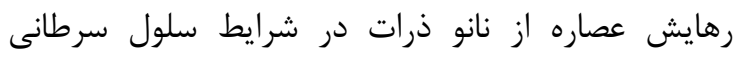
بيشتر بوده و حدكثر رهايش عصاره Artemisia

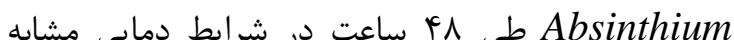

\section{Calculation Results}

\begin{tabular}{|c|c|c|c|c|}
\hline Peak No. & S.P.Area Ratio & Mean & S.D. & Mode \\
\hline 1 & 1.00 & $141.9 \mathrm{~nm}$ & $57.7 \mathrm{~nm}$ & $129.4 \mathrm{~nm}$ \\
\hline 2 & -- & $-\mathrm{nm}$ & $-\mathrm{nm}$ & $-\mathrm{nm}$ \\
\hline 3 & $\cdots$ & $-\mathrm{nm}$ & $-\mathrm{nm}$ & $--\mathrm{nm}$ \\
\hline Total & 1.00 & $141.9 \mathrm{~nm}$ & $57.7 \mathrm{~nm}$ & $129.4 \mathrm{~nm}$ \\
\hline
\end{tabular}

\section{Cumulant Operations} Z-Average

PI
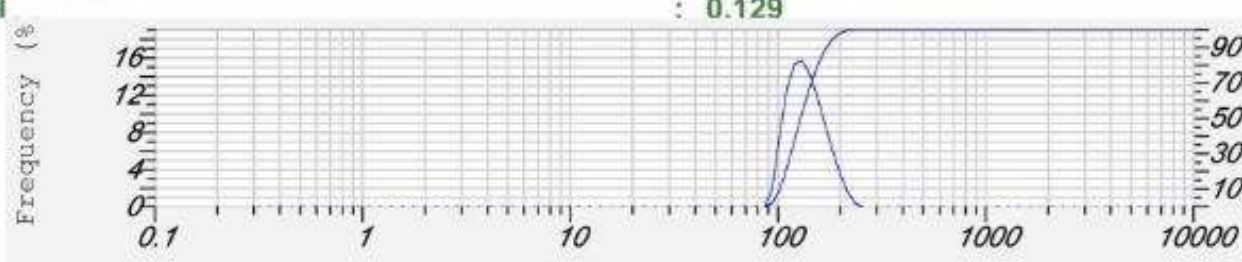

Diameter (nm)

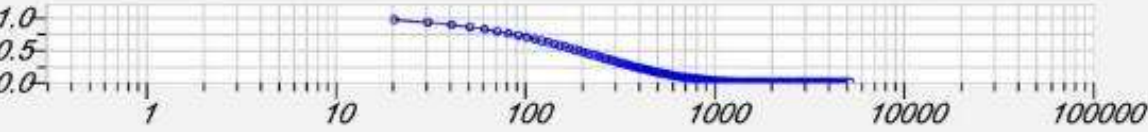

Delay Time ( $\mu \mathrm{s})$
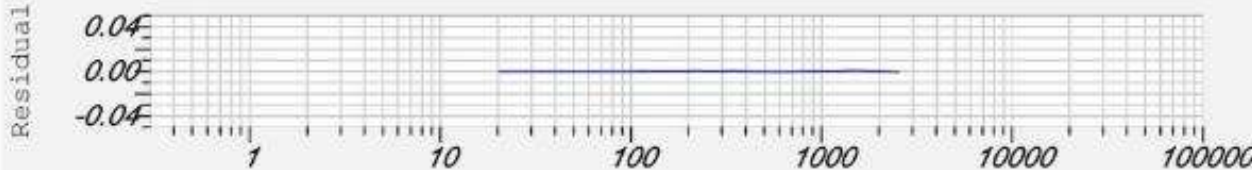
Calculation Results

\begin{tabular}{|c|c|c|}
\hline Peak No. & Zeta Potential & Electrophoretic Mobility \\
\hline 1 & $-10.6 \mathrm{mV}$ & $-0.000502 \mathrm{~cm} 2 \mathrm{Ns}$ \\
\hline 2 & $-\mathrm{mV}$ & $-\mathrm{cm} 2 \mathrm{Ns}$ \\
\hline 3 & $-\mathrm{mV}$ & $-\mathrm{cm} 2 \mathrm{Ns}$ \\
\hline \multicolumn{2}{|c|}{ Zeta Potential (Mean) } \\
\hline
\end{tabular}

Electrophoretic Mobility Mean : $-0.000502 \mathrm{~cm}^{2} / \mathrm{Ns}$

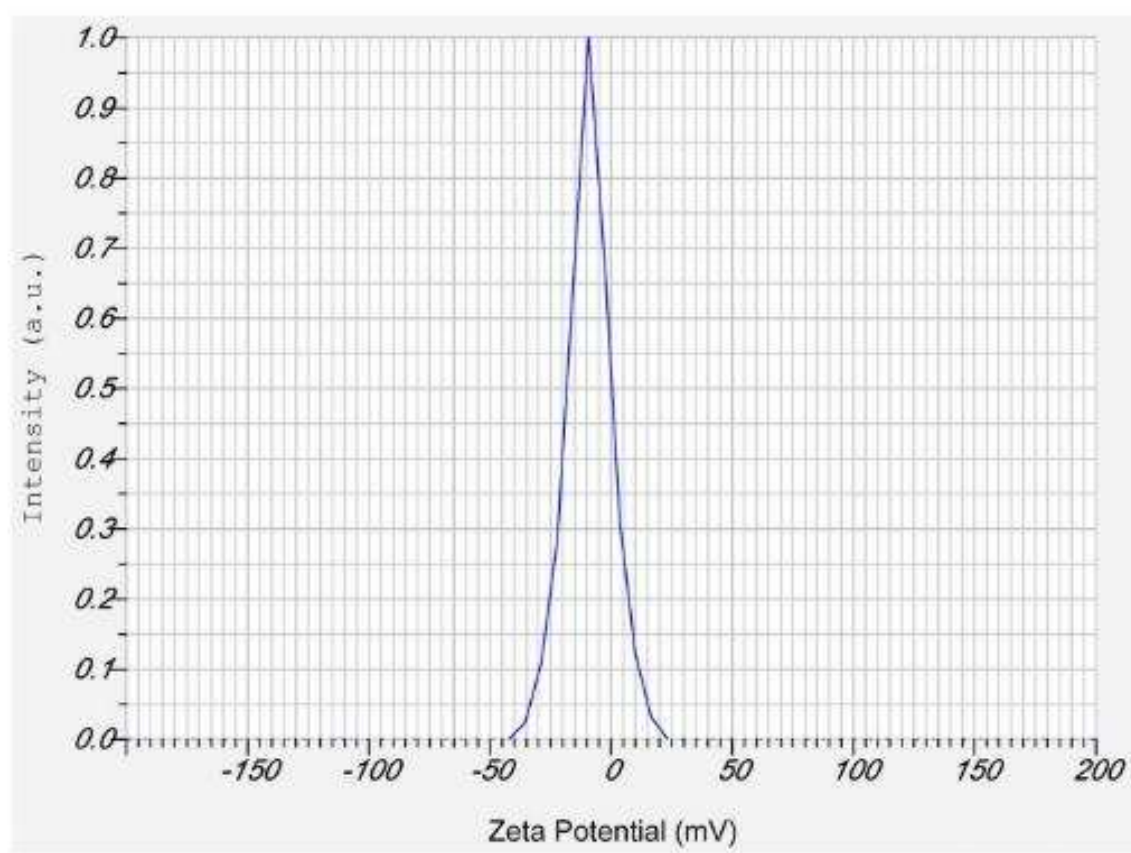

تصوير r: پيتانسيل زتاى نانوذرات ليبيوزومال حاوى عصاره Artemisia Absinthium

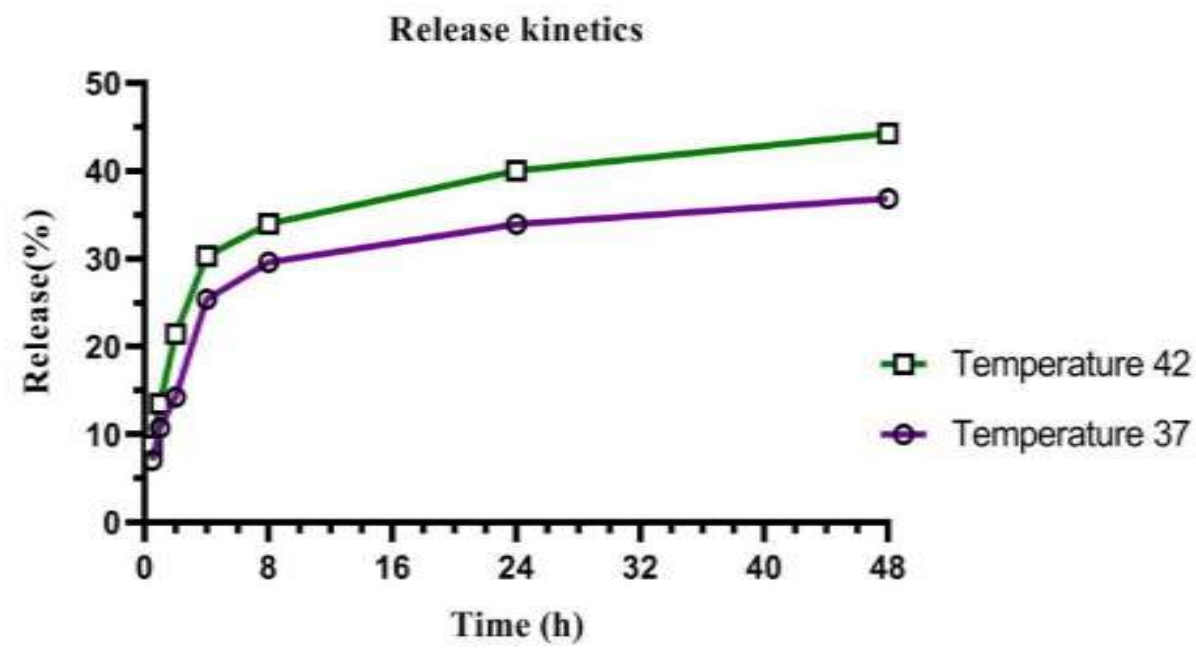

نمودار ץّ: نمودار رهايش عصاره Artemisia asintium طى f^ ساعت در دماى r 


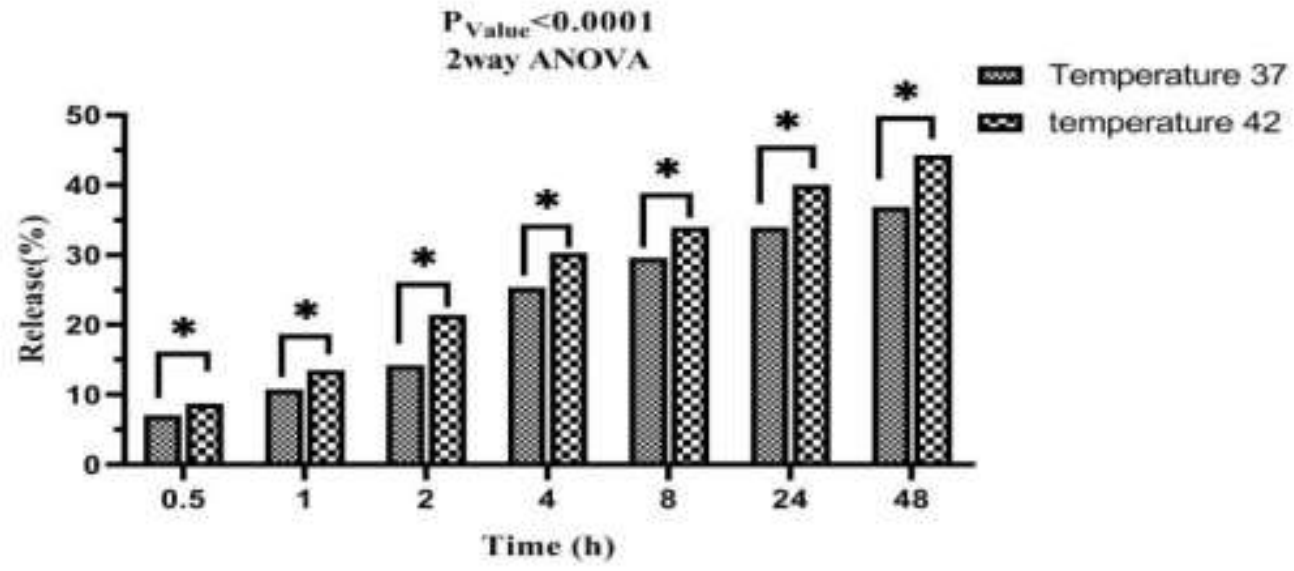

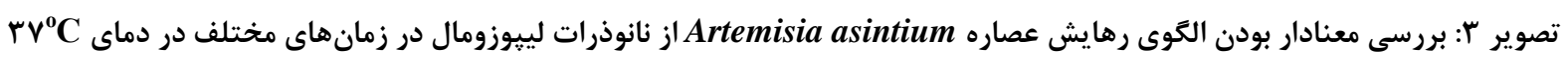

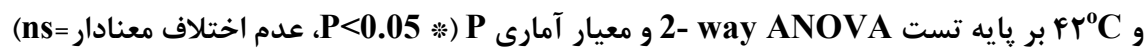

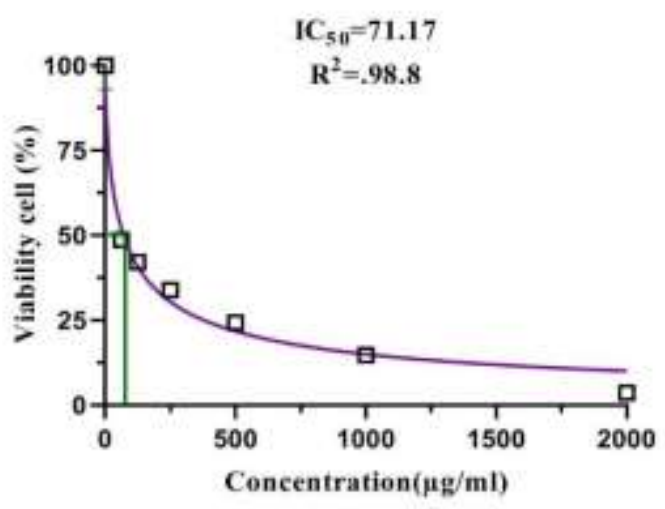

Artemisia نمودار ه: MCF-7 بbsinthium

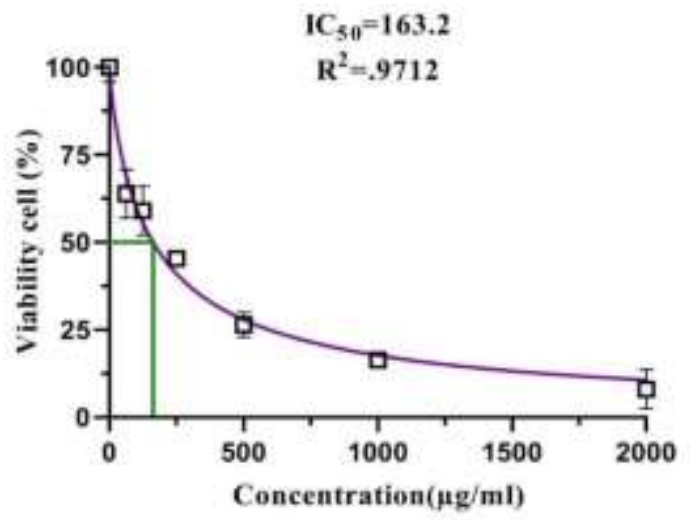

نمودار \$ \& عصاره آزاد Artemisia Absinthium بر رده

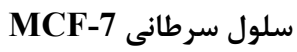

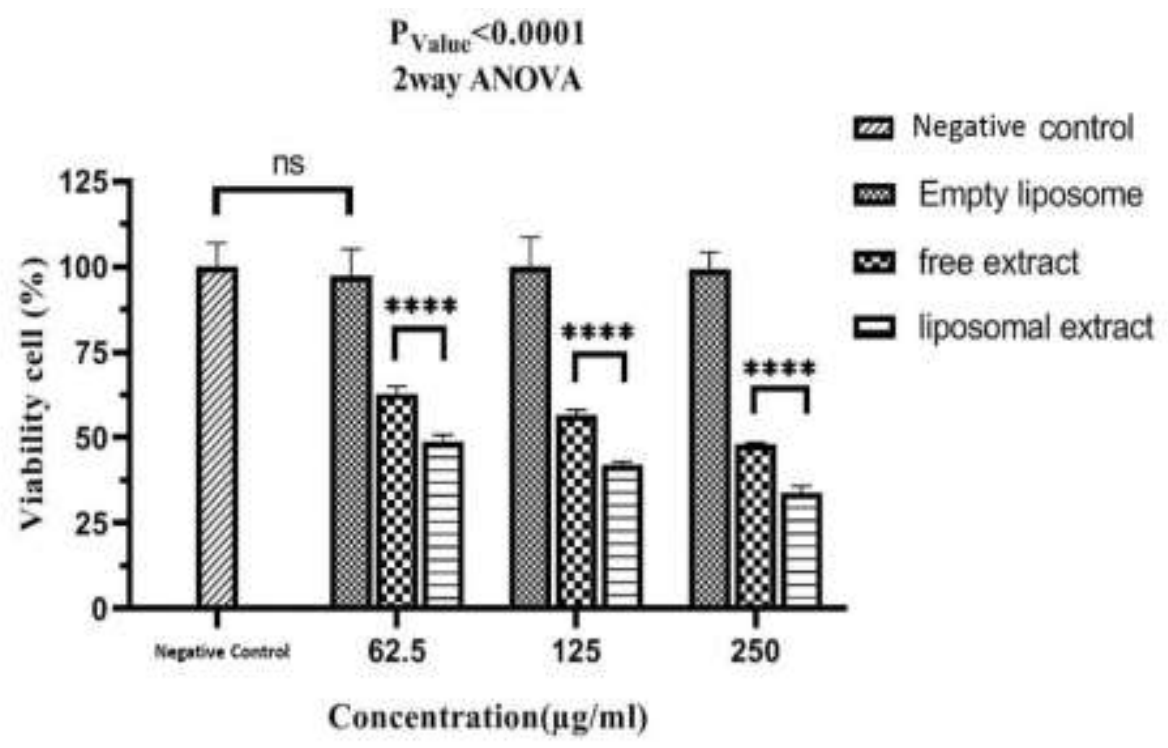

نمودار \&: درصد زندهمانى سلول MCF-7 در مواجه با عصاره آزاد Artemisia Absinthium، ليبوزم خالى و ليبوزوم حاوى عصاره

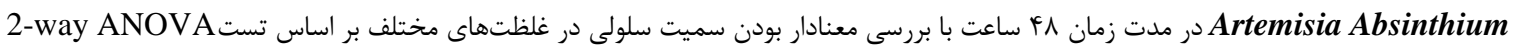

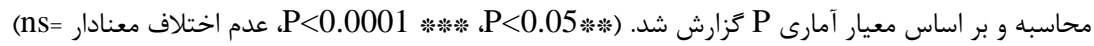


افزايش يافته است. در فرمولاسيون F3 مانند فرمولاسيون

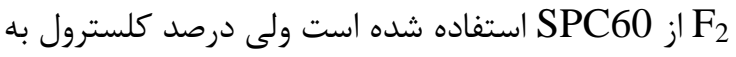
كار رفته در ساختار آن افزايش ييدا نموده است. در نتيجه

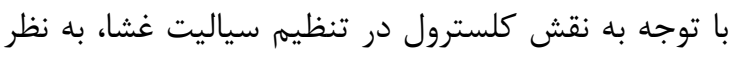

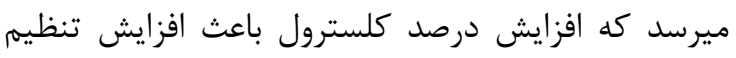

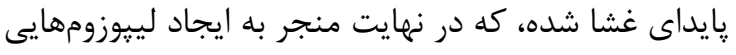

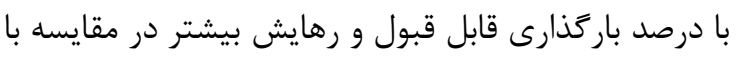

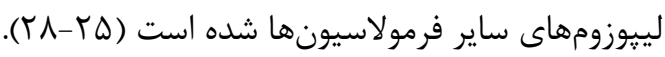

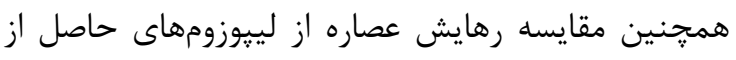

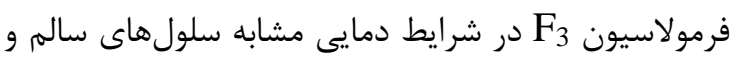

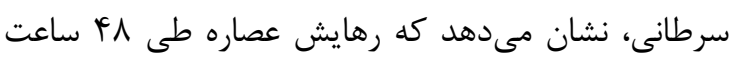

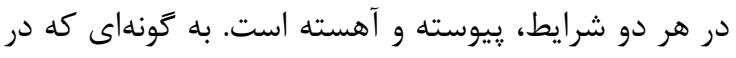
ابتداى رهايش بهدليل غلطت بالاى عصاره درون لييوزوم بـونئه

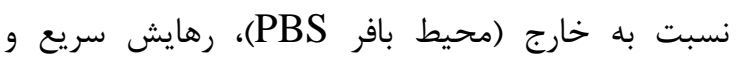

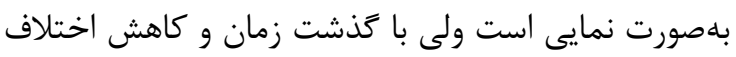

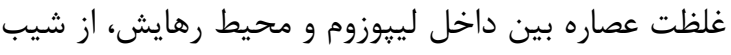

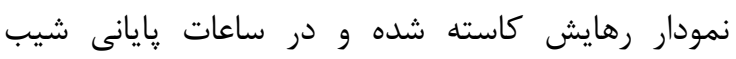
رهايش به صفر نزديك شده است. نتايج اين بخش ازئه

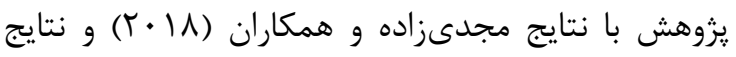

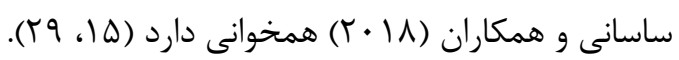
جنبه ديخرى كه در يزوهش حاضر مورد بررسى قرار كرفته (برانه

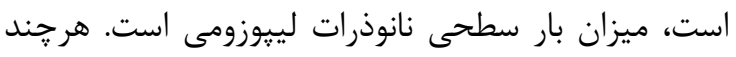

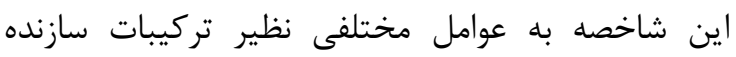

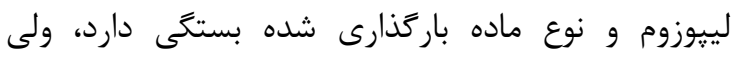

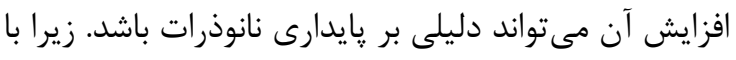

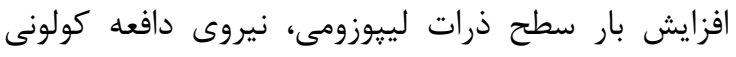

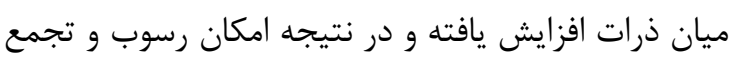

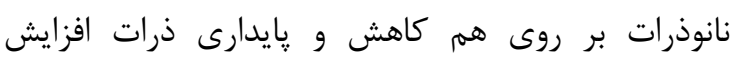

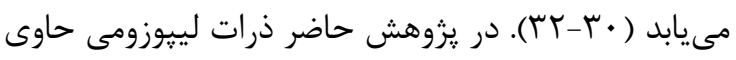

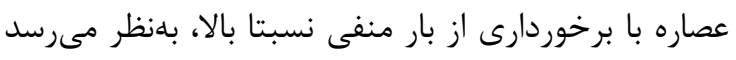

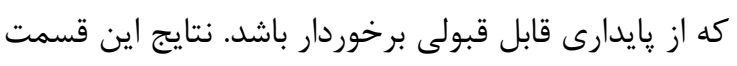

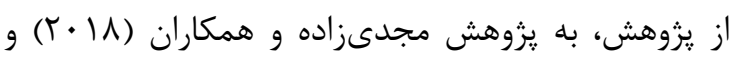

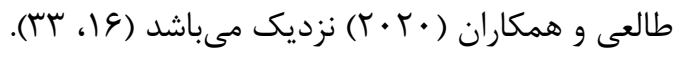

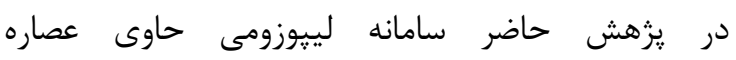
Artemisia Absinthium سميت بالايى برخوردار است و با توجه به اينكه بررسىهاى آمارى معنادار بودن اين تفاوت رات را نشان مىدهد، مىتوان نتيجه كرفت كه سامانه ليبيوزومى حاوى آناري

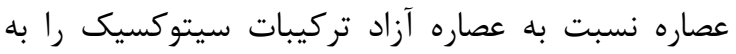

استفاده از تركيبات سيتوتوكسيك َياهى مىتواند

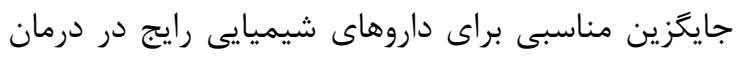

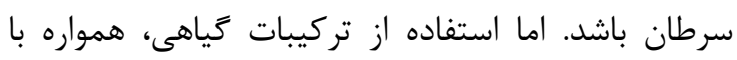

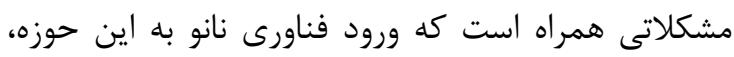

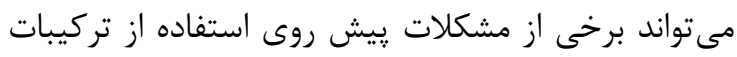

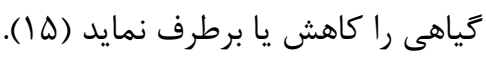

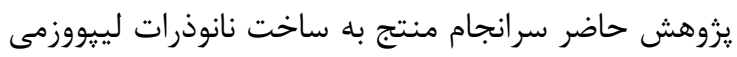
حاوى عصاره Artemisia Absinthium با اندازه ذرات

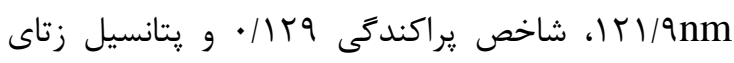
19mV

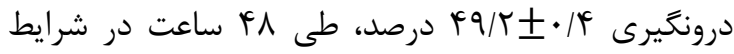

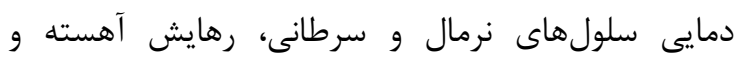

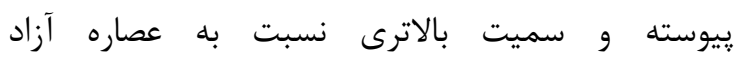
MCF-7 بrtemisia Absinthium

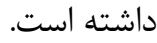
يكى از جنبههاى مورد بحث در يزتوهش حاضر، تاثير

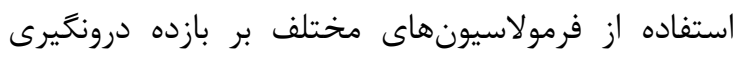

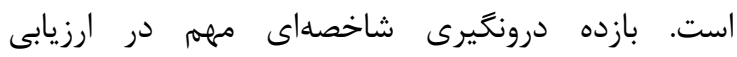

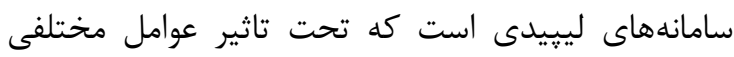

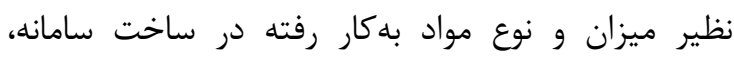
ماهيت ماده باركذارى شده، روش ساخت و غيره، مى تواند

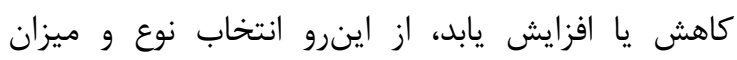

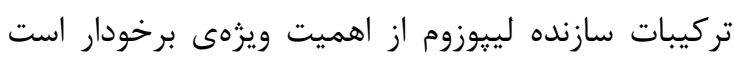

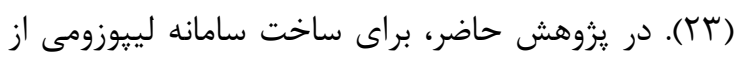

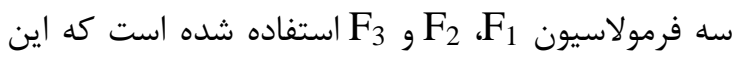

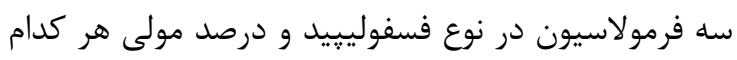

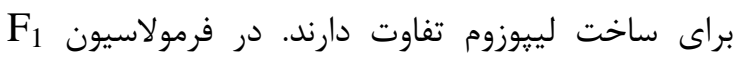

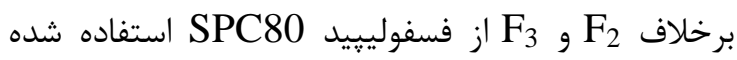

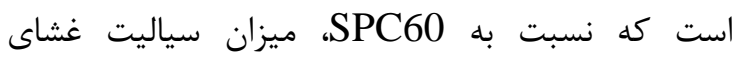
لييوزوم را كاهش مى دهد، بنابراين از نشت مواد بار كذارى نه

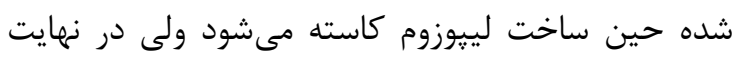
منجر به كاهش رهايش عصاره خواهد شد. زيرا زنجيرهناى لهاى

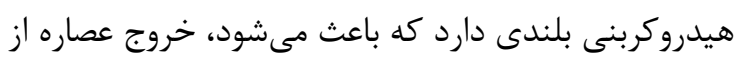

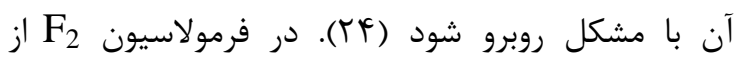
فسفوليييد SPC60 استفاده شده است كه نسبت به سياليت غشا را افزايش داده و در نتيجه، ميزان SPC80

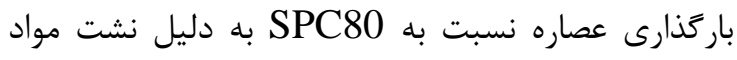
كاهش يافته ولى رهايش آن نسبت به فرمولاسيون 
شده است (•l). در يزوهش حاضر اندازه ذرات كوجكتر،

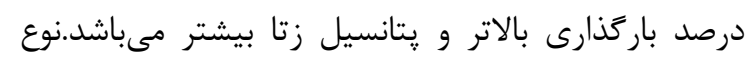

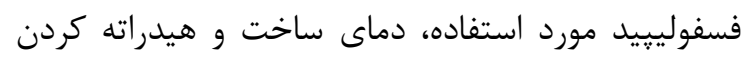

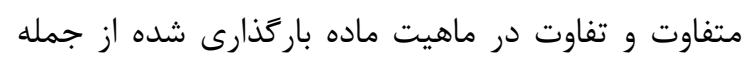

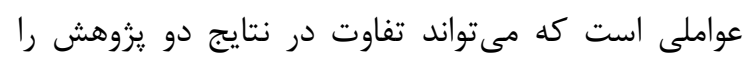
توجيه نمايد.

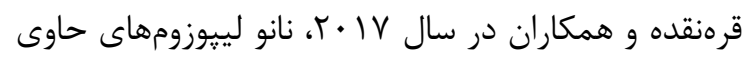

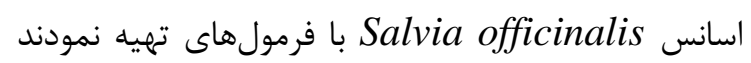

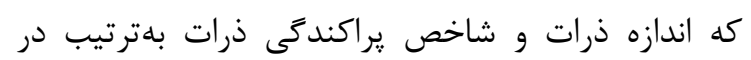

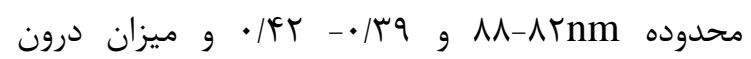

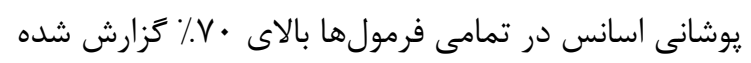

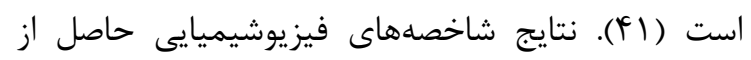

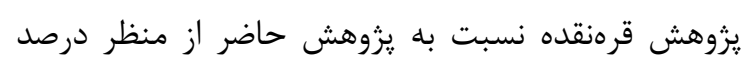

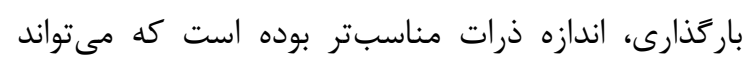

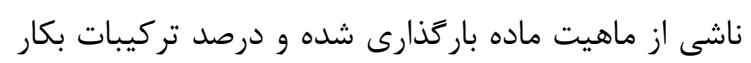
رفته در ساختار ذرات لييوزومى باشد.

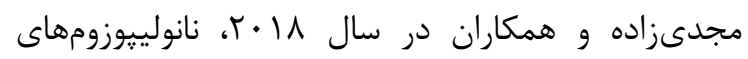
حاوى اسانس Menthapiperita تهييه نمودند

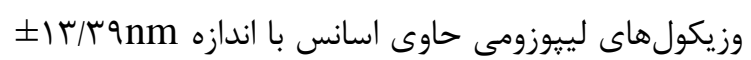
نتانسيا،

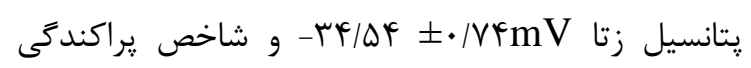

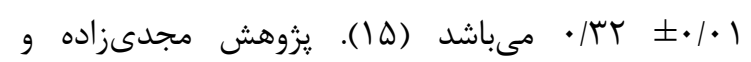

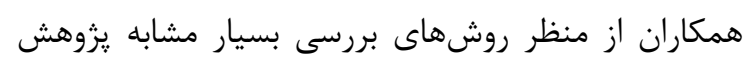

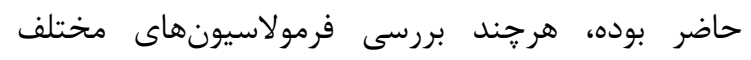

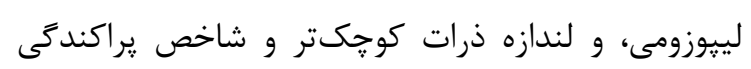

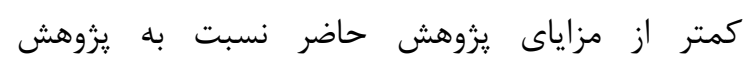

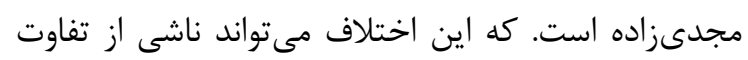

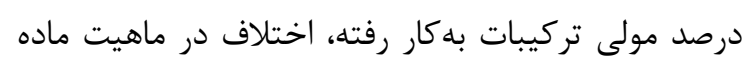
باركذارى شده و دماى ساخت لييوزوم باشد.

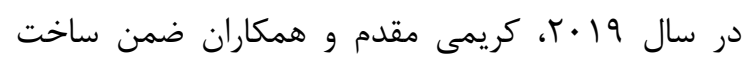
سامانه لييوزومى حاوى سيليبينين، نشان دادند كه ذرات ذرات

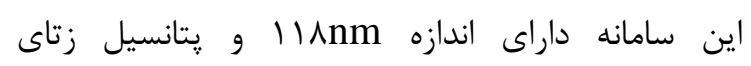

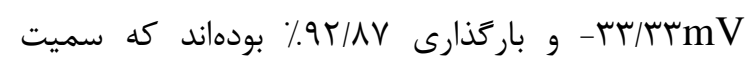
MCF- بالاترى را نسبت به سيليبينين آزاد بر رده سلوكاري

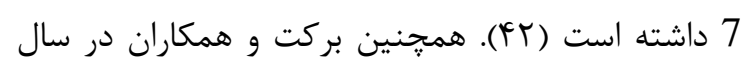
19 • ب، سامانه لييوزومى حاوى عصاره Nepetapersica

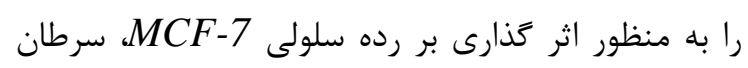

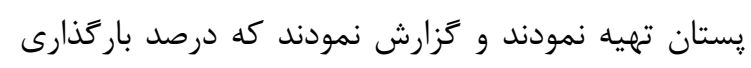

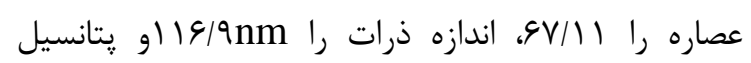

نحو موثرترى در اختيار سلولهاى سرطانى قرار داده است،

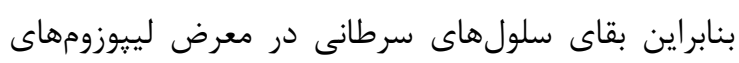
حاوى عصاره در تمامى غلظت ها در مقايسه بائ بائ عصاره آزاد Artemisia asintium بيشتر مىتواند ناشى ورود سامانه به درون سلول سرطانى النى

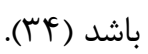

تاكنون يزوهش باشن (باى متفاوتى بر روى سامانههاى ليبيدى

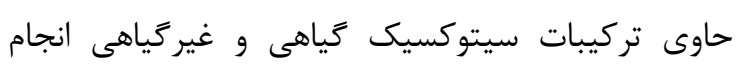
شده است كه به بخشى از آن اشاره مىشود. Detoni و و

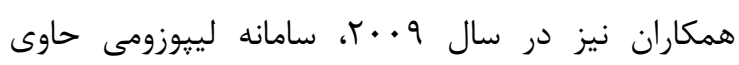

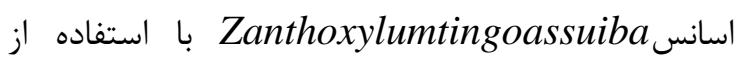

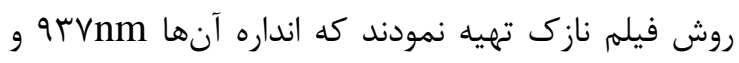

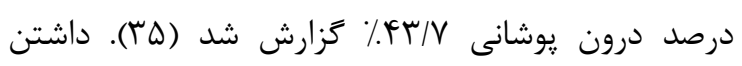

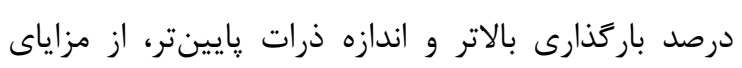

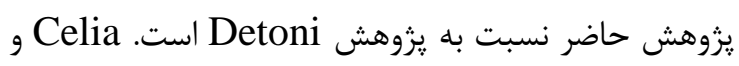

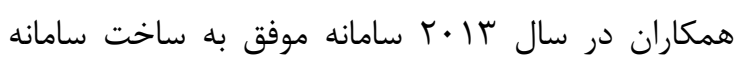

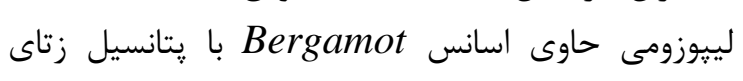
9 mV

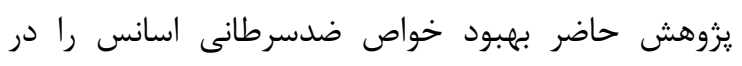

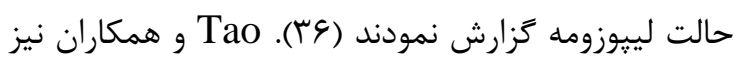

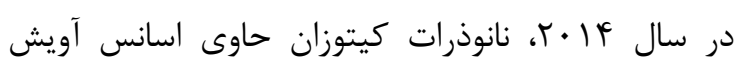

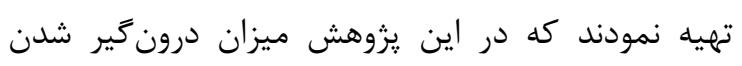

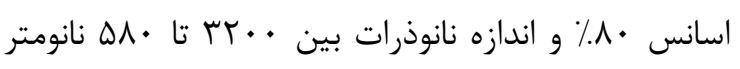

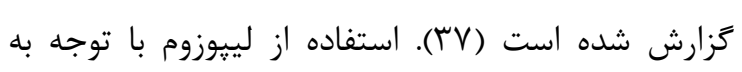

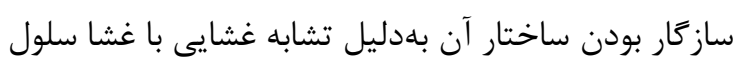

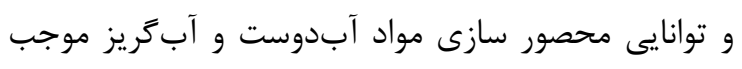

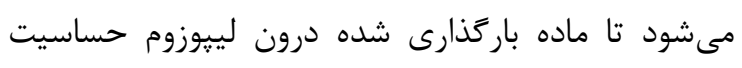

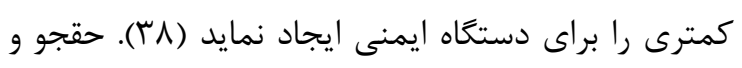

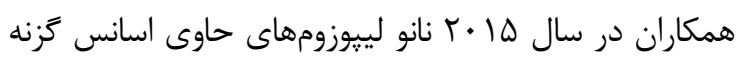
در غلظتهاى مختلفى از فسفاتيديل كولين و كلسترول تهيه

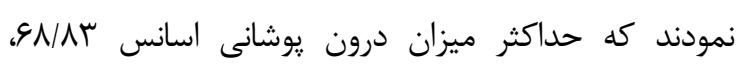

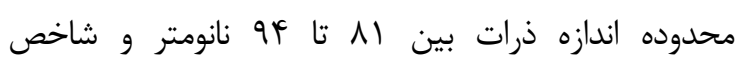

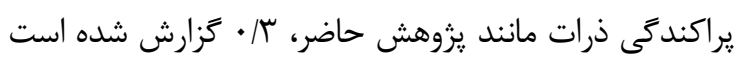

حقيرالسادات و همكاران در سال 1 • • ب نانو ذرات ليبيدى

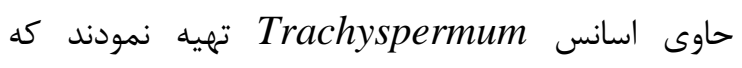

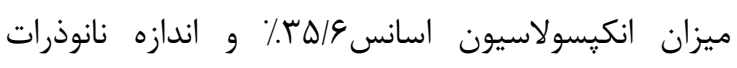

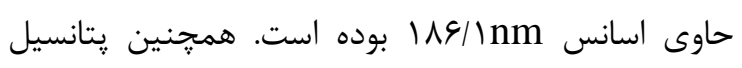

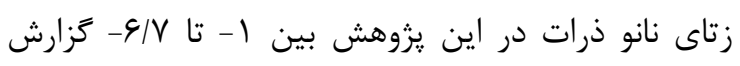


يزوهشها، داراى كاستىهايى است. عدم استفاده از

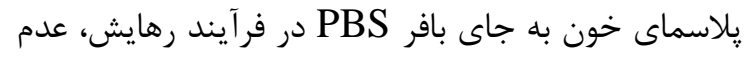

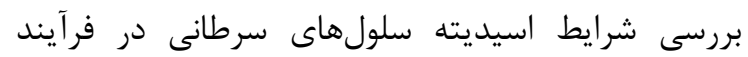

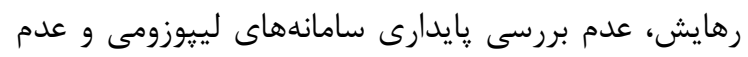

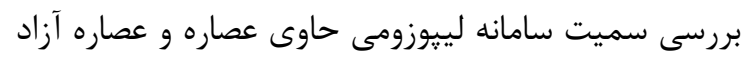

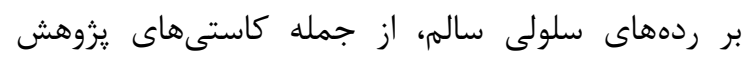

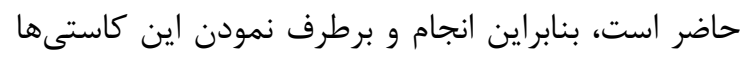
به يزوهشكران بعدى در اين حوزه يِيشنهاد مىشود.

\section{نتيجهكيرى}

سميت بالاى حاصل سامانه لييوزومى حاوى عصاره نسبت

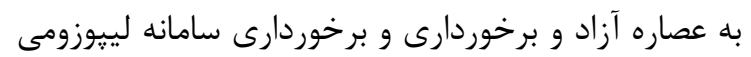
حاوى عصاره Artemisia Absinthium از ويز كى هاى فيزيكوشيميايى مناسب نشان ميدهد مهد كهاين سامانه

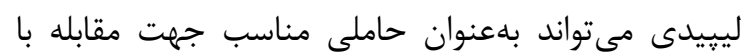
سلولهاى سرطانى به محققان حوزه سرطان درمانى

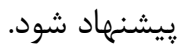

\section{تعارض در منافع}

هيجَّونه تعارض در منافعى از سوى نويسندگان كزارش

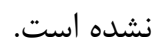

\section{References}

1. Kamble SS, Gacche RN. Evaluation of antibreast cancer, anti-angiogenic and antioxidant properties of selected medicinal plants. European Journal of Integrative Medicine. 2019; 25:13-9.

2. Bray F, Ferlay J, Soerjomataram I, Siegel RL, Torre LA, Jemal A. Global cancer statistics 2018: GLOBOCAN estimates of incidence and mortality worldwide for 36 cancers in 185 countries. CA: a cancer journal for clinicians. 2018; 68(6):394-424.

3. Chakraborty S, Rahman T. The difficulties in cancer treatment. Ecancermedicalscience. 2012; 6:ed16.

4. Qiao Y, Wan J, Zhou L, Ma W, Yang Y, Luo $\mathrm{W}$, $\mathrm{Yu} \mathrm{Z}$, Wang $\mathrm{H}$. Stimuli-responsive

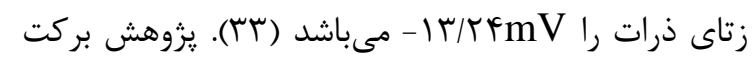

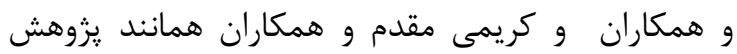
حاضر نشان داد كه كه تركيبات لييوزومه شده نسبت به به دان

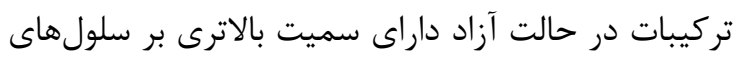
سرطانى مىباشد. طالعى اردكانى و همكاران در سال درال

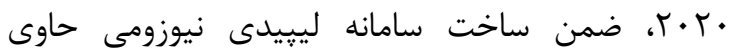

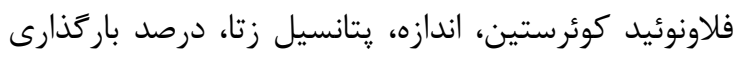

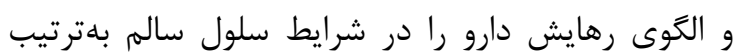
IV·nm

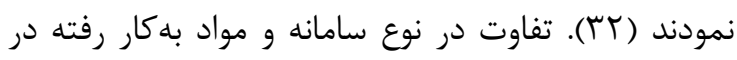

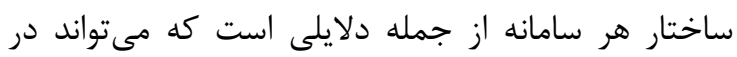
نتايج دو يزوهش ياد شده تفاوت ايجاد نمايد.

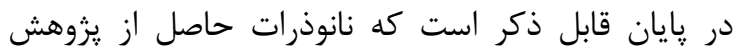

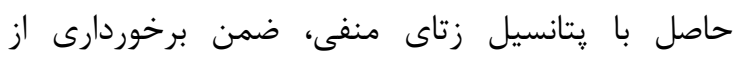

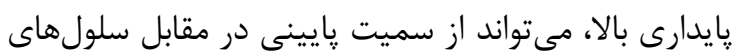
سالم بدن برخوردار باشد. همجنين رهايش كنترل شده و

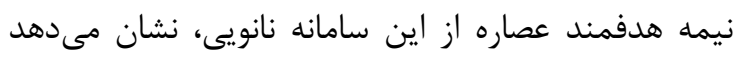

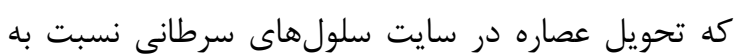
سلولهاى سالم از بازده بالاترى برخوردار است. بنابراين

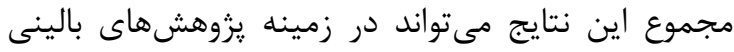

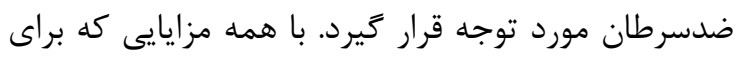
نتايج يزوهش بيان شد، يزوهش حاضر مانند بسيارى از nanotherapeutics for precision drug delivery and cancer therapy. Wiley Interdisciplinary Reviews: Nanomedicine and Nanobiotechnology. 2019; 11(1):e1527.

5. Dolatkhah R, Somi MH, Asghari-Jafarabadi M, Hosseinalifam M, Sepahi S, Belalzadeh M, Nezamdoust M, Dastgiri S. Breast Cancer Survival and Incidence: 10 Years Cancer Registry Data in the Northwest, Iran. International Journal of Breast Cancer. 2020; 1(1):1-6

6. Sadjadi A, Nouraie M, Ghorbani A, Alimohammadian M, Malekzadeh R. Epidemiology of breast cancer in the Islamic Republic of Iran: first results from a population-based cancer registry. Eastern 
Mediterranean Health Journal. 2009; 15(6): 1427-31.

7. Danaei M, Haghdoost A, Momeni M. An Epidemiological Review of Common Cancers in Iran; A Review Article. Iranian Journal of Blood and Cancer. 2019; 11(3):77-84.

8. Wang $\mathrm{X}$, Zhang $\mathrm{H}$, Chen $\mathrm{X}$. Drug resistance and combating drug resistance in cancer. Cancer Drug Resist. 2019; 2:141-60.

9. Oun R, Moussa YE, Wheate NJ. The side effects of platinum- based chemotherapy drugs: a review for chemists. Dalton transactions. 2018; 47(19):6645-53.

10. Abotaleb M, Samuel SM, Varghese E, Varghese S, Kubatka P, Liskova A, Büsselberg D. Flavonoids in cancer and apoptosis. Cancers. 2019; 11(1):28.

11. Singh R, Verma PK, Singh G. Total phenolic, flavonoids and tannin contents in different extracts of Artemisia absinthium. Journal of Complementary Medicine Research. 2012; 1(2):101-4.

12. Batiha GE, Olatunde A, El-Mleeh A, Hetta $\mathrm{HF}$, Al-Rejaie S, Alghamdi S, Zahoor M, Magdy Beshbishy A, Murata T, ZaragozaBastida A, Rivero-Perez N. Bioactive compounds, pharmacological actions, and pharmacokinetics of wormwood (Artemisia absinthium). Antibiotics. 2020; 9(6):353.

13. Koyuncu I. Evaluation of anticancer, antioxidant activity and phenolic compounds of Artemisia absinthium L. Extract. Cell Mol Biol (Noisy-le-grand). 2018; 64(3):25-34.

14. Rezaeinodehi A, Khangholi S. Chemical composition of the essential oil of Artemisia absinthium growing wild in Iran. Pak J Biol Sci. 2008;11(6):946-9.

15. Majdizadeh M, Rezaei Zarchi S, Movahedpour AA, Shahi Malmir H, Sasani E, Haghiralsadat BF. A new strategy in improving therapeutic indexes of medicinal herbs: preparation and characterization of nano-liposomes containing Mentha piperita essential oil. SSU_Journals. 2018; 25(11): 853-64.

16. Mohanraj VJ, Chen Y. Nanoparticles-a review. Tropical journal of pharmaceutical research. 2006; 5(1):561-73.

17. Hoseinizadeh MJ. An overview of the most important mechanisms and systems of targeted drug delivery.Scientific research applied biology. 2016; 6(21): 17-28

18. Rabani E, Behzadi R, Majdizadeh M, Haghiralsadat B F. Fabrication of liposomal formulation containing paclitaxel and comparison of its toxicity with non-liposomal paclitaxel on MCF-7 breast cancer cell line.
Journal of Jahrom University of Medical Sciences. 2020; 18 (2) :26-40.

19. Wolfram J, Ferrari M. Clinical cancer nanomedicine. Nano Today. 2019; 25:85-98.

20. Shahi Malmir H, Kalantar S M, Sasani E, Asgari M, Majdizadeh M, Haghiralsadat B F. Synthesis and optimization of niosomal carriers containing doxorubicin in order to achieve a final formulation with high potential in cancer cells temperature and acidity. JSSU. 2019; 26(10) :879-94.

21. Jamalzadeh L, Ghafoori H, Sariri R. Evaluation of anti-proliferative activity of a semi-synthetic derivative of artemisininartesunate in MCF-7 human breast cancer cell line. Journal of Cell \& Tissue (JCT) Original Article Spring. 2016; 7(1): 45-57

22. Bashash D, Safa M, Shahbazi A, Mohammadian M, Shah-Mohammad N. Apoptotic Effect of milk thistle extract on human breast cancer MCF-7 cell. Complementary Medicine Journal. 2012; 2(1): 85-95.

23. Kulkarni SB, Betageri GV, Singh M. Factors affecting microencapsulation of drugs in liposomes. Journal of microencapsulation. 1995; 12(3):229-46.

24. van Hoogevest P. Review-An update on the use of oral phospholipid excipients. European Journal of Pharmaceutical Sciences. 2017; 108:1-12.

25. Tiberg F, Johnsson M, Jankunec M, Barauskas J. Chem. Lett. 2012; 41(1):1090-2. https://doi.org/10.1246/cl.2012.1090

26. Momo F, Fabris S, Stevanato R. Interaction of fluoxetine with phosphatidylcholine liposomes. Biophysical chemistry. 2005; 118(1):15-21.

27. Pezeshky A, Ghanbarzadeh B, Hamishehkar H, Moghadam M, Babazadeh A.Vitamin A palmitate-bearing nanoliposomes: Preparation and characterization. Food bioscience. 2016; 13:49-55.

28. Ghanbarzadeh B, Pezeshki A, Hamishekar H, Moghaddam M. Vitamin A palimitate-loaded nanoliposomes: study of particle size, zeta potential, efficiency and stability of encapsulation. Iranian Food Science and Technology Research Journal. 2016; 12(2): 261-75.

29. Sasani E, Shahi Malmir H, Daneshmand F, Majdizadeh M, Haghiralsadat B F. A new study on synthesize and optimization of PEGylated LipoNiosomal nanocarriers containing curcumin for use in cancer chemotherapy. JSSU. 2018; 26 (6):528-41. 
30. Honary S, Zahir F. Effect of zeta potential on the properties of nano-drug delivery systems-a review (Part 2). Tropical Journal of Pharmaceutical Research. 2013;12(2):265-73.

31. Zhao W, Song Zhuang X-RQ. Comparative study of the in vitro and in vivo characteristics of cationic and neutral liposomes. International journal of nanomedicine. Dove Press. 2011; 6:3087.

32. Danhier F, Feron O, Préat V. To exploit the tumor microenvironment: passive and active tumor targeting of nanocarriers for anti-cancer drug delivery. Journal of ControlledRelease. Elsevier. 2010; 148(2):135-46.

33. Talei-Ardakani N, Daneshmand F, Mirhoseini M, Ebrahimpour M, Majdizadeh M. Haghiralsadat BF. Fabrication and characterization of physicochemical niosomal nano- carriers containing quercetinflavonoidsfor therapeutic purposes. Journal of Knowledge \& Health in Basic Medical Sciences. 2020; 15(1):32-40.

34. Barakat F, Aboee-Mehrizi F, Haghiralsadat B F, Dehghani Ashkezari M. Designing and optimization of liposomal nano-carriers containing Nepeta persica extract and study of its cytotoxicity on the breast cancer cell line (MCF-7). JSSU. 2019; 27(2) :1202-15.

35. Detoni CB, Hohlemweger SVA, Sampaio C, Barros TF. Essential oil from Zanthoxylum tingoassuiba loaded into multilamellar liposomes useful as antimicrobial agents. J Microencapsul. 2009; 26(8):684-91.

36. Celia C, Trapasso E, Locatelli M, Navarra M, Ventura CA, Wolfram J, Carafa M, Morittu VM, Britti D, Di Marzio L PD. Anticancer activity of liposomal bergamot essential oil (BEO) on human neuroblastoma cells. Colloids Surf B Biointerfaces. 2013; 112:548-
53.

37. Tao F, Hill L, Peng Y, Gomes C. Synthesis and characterization of $\beta$-cyclodextrin inclusion complexes of thymol and thyme oil for antimicrobial delivery applications. LWTFood Sci Technol. 2014; 59(1):247-55.

38. Bozorgnejad A, Baghi F, Zamanpour niavaran A, Akbarzadeh A, Arjmand M. Nanocarrier Liposome Production from Lecithin and Cisplatin Loading on it. NCMBJ. 2012; 2(7):91-6.

39. Haghjoo S, Ghanbarzadeh B, Hamishekar H, Asnaashari S, Dehghannia J. Evaluation of colloidal and antioxidant properties of nano liposomes containing nettle extract. Innov Food Technol. 2015; 2(7):11-23.

40. Haghiralsadat F, Azhdari M, Kalantar SM, Nadernezhad S, Teymorizadeh K, Yazdani M, et al. Strategy of Improvements in the rapeutic index of medicinal herbs of Iranianin digenous: Synthesis and characterization of phospholipid lipid-based vesicles in corporated Trachyspermum copticum. J Shahid Sadoughi Univ Med Sci. 2016; 24(6): 468-78.

41. Gharenaghadeh S, Samadlouie HR, Sowti M, Hamisekar H, Mokaram RR. Evaluation of the antimicrobial and antioxidant properties of Salvia essential oil nano liposome (Salvia multicaulis). JFST. 2017; 14(62):271-82.

42. Karimi-Moghddam A, Nikoonahad Lotfabadi $\mathrm{N}$, Haghiralsadat BF, Majdizadeh $\mathrm{M}$. Investigating the effect of lipid nanoparticles containing silibinin anti-cancer drug on the growth of breast cancer MCF-7 cell line. Journal of Torbat Heydariyeh University of Medical Sciences. 2018; 6(4):1-12. 